\title{
Analisis Pengembangan Perpustakaan Berdasarkan SNI 7330:2009 PPT Sebagai Kualitas Perpustakaan
}

\author{
(Studi Evaluatif Tentang Pengembangan Perpustakaan berdasarkan SNI 7330:2009 \\ $P P T$ yang belum Tercapai di Perpustakaan Pusat ITB)
}

\author{
Alice Diniarti, Rohanda, dan Dian Sinaga \\ Institut Teknologi Bandung \& Universitas Padjadjaran \\ Jl. Ganesha No. 10, Bandung 40132 \\ Jl. Raya Bandung-Sumedang Km. 21 Jatinangor 45363 \\ Email: diniartia@yahoo.com
}

\begin{abstract}
ABSTRAK - Proses pengembangan organisasi/ perpustakaan yang sesuai dengan standar perpustakaan yang berkualitas, diperlukan proses analisis faktorfaktor yang ada di perpustakaan. Pengembangan perpustakaan merupakan sebuah pengambilan keputusan yang tepat yang akan dilaksanakan, dan hal tersebut sangat ditentukan oleh perencanaan yang baik. Dalam menyusun rencana pengembangan, diperlukan langkah-langkah pengumpulan data, penetapan tujuan, analisis faktor lingkungan. Pengembangan standar perpustakaan yang masih relevan saat ini adalah berdasarkan SNI 7330:2009 PPT. Dalam penelitian ini, menggunakan teori sistem dengan penelitian kualitataif pendekatan analisis evaluatif. Penelitian ini mengkaji faktor-faktor pengembangan perpustakaan di Perpustakaan Pusat ITB, diantaranya adalah; layanan, fasilitas, SDM, anggaran, dan sebagainya. Namun, tidak semua faktor-faktor dari pengembangan perpustakaan telah memenuhi standar pengembangan perpustakaan, Oleh karena itu, penulis ingin meneliti mengenai hal tersebut. Kesimpulannya adalah dalam pengembangan perpustakaan diperlukan sistem strategi perencanaan organisasi agar sebuah organisasi dapat berjalan dengan baik sesuai dengan tujuan dan kebutuhan.
\end{abstract}

Kata Kunci: Pengembangan Organisasi, Kualitas Perpustakaan, SNI PPT, Rencana Strategi

ABSTRACT - The process of organization development to be able to quality of library standard is needed to analize library factors. Library development is a decision-making that must be implemented and it is determined by a good planning. To arranging development of planning is necessary to plan the steps data collection, goal setting, environment analysis. The standardization of Library development is still relevant to Library development today is SNI 7330:2009 PPT. On this research used a system theory and the Qualitative methology on evaluative analysis. The research is analizing the factors of Library development in ITB library, among are; the service, facilities, human resource, budgeting, and etc. The result are shown that not all of the factors of library development has to be fulfill the standardization of library development, Therefore, the researcher wanted to examine it. The conclusion is the library development needed to make an organization planning of strategy system that in order to goals and needs accordance.

Keywords: Organization Development, Library Quality, SNI PPT, planning of strategy

\section{PENDAHULUAN \\ Latar Belakang Penelitian}

Pengembangan organisasi merupakan landasan untuk melaksanakan visi dan misi suatu organisasi. Secara definisi, perencanaan pengembangan organisasi adalah hasil sistematis dari proses pemikiran yang memungkinkan organisasi perpustakaan untuk mengatur usahausaha yang diperlukan untuk menjalankan keputusan-keputusannya dan untuk mengukur keputusan supaya mendapatkan harapan yang diinginkan melalui umpan balik yang terorganisir dan sistematis, serta berbagai penyesuaian (Stueart \& Moran, 2002). Berdasarkan definisi tersebut dapat dikemukakan bahwa dalam proses pengembangan organisasi/perpustakaan yang sesuai dengan standar perpustakaan yang berkualitas, diperlukan proses analisis faktorfaktor yang ada di perpustakaan.

Perpustakaan Institut Teknologi Bandung (Perpustakaan ITB) sebagai lembaga informasi yang berfungsi sebagai penunjang kegiatan dalam rangka melaksanakan Tridharma Perguruan Tinggi yaitu pendidikan, penelitian dan pengabdian masyarakat, dituntut untuk mampu memberikan layanan yang sesuai dengan kebutuhan Sivitas akademikanya (Siva). Oleh karena itu, dalam menjalankan fungsinya, perpustakaan harus melihat beberapa aspek penting yang dimilikinya, 
salah satunya adalah siva, yaitu dosen (staff pengajar) dan mahasiswa.

Peningkatan jumlah mahasiswa dari tahun ke tahun, mengharuskan penambahan kuota mahasiswa baru $10 \%$ dari penerimaan tahun sebelumnya, sesuai anjuran Kementrian Pendidikan Nasional (Kemdiknas), hal ini berdampak terhadap peningkatan jumlah pengguna di Perpustakaan, karena mahasiswa adalah kelompok pengguna terbesar pada perpustakaan selain dosen. Dari statistik kunjungan maupun peminjaman pustaka oleh mahasiswa mengalami peningkatan yang cukup signifikan, data kunjungan bulan maret 2013 sebanyak 48.008 siswa $^{1}$, rata-rata perhari kunjungan ke perpustakaan, bila diasumsikan satu bulan 20 hari kerja, dikunjungi 24000 siva.

Perkembangan Perpustakaan berdampak pada Visi dan Misi ITB, apalagi dengan dibukanya program studi yang baru, baik di kampus ITB Ganesa maupun program studi baru di ITB Kampus Jatinangor. Untuk itu, perpustakaan harus membuat perencanaan untuk pengembangannya dan sesuai dengan standarisasi kualitas pelayanan perpustakaan perguruan tinggi. Hal ini berkaitan erat dengan Standar Nasional Indonesia Perpustakaan Perguruan Tinggi (SNI PPT) berdasarkan SIN 7330:2009 PPT, perencanaan menyangkut pengembangan fungsi gedung, koleksi bahan pustaka Buku Teks, Jurnal Ilmiah, Koleksi digital Jurnal Elektronik, koleksi digital Buku Elektronik, Sumber Daya Pustakawan dan Tata Kelola Organisasi juga Sarana dan Prasarana (Renstra Perpustakaan ITB, 2011). Dengan perencanaan sebuah perpustakaan, maka akan berpengaruh pada kualitas perpustakaan itu sendiri, perencanaan yang baik maka akan menghasilkan kualitas perpustakaan sebagai palayanan prima bagi para pemustaka.

Pada dasarnya, tujuan daripada perpustakaan perguruan tinggi adalah mendukung kinerja dari perguruan tinggi dalam menyelenggarakan pendidikan dengan menyediakan sumber-sumber informasi ilmiah di perpustakaan tersebut dan selalu melayani pengguna (mahasiswa), selama menjalankan pendidikan di perguruan tinggi yang bersangkutan. Di Perpustakaan perguruan tinggi, para pustakawan ditutntut untuk dapat memberikan pelayanan secara profesional dalam melaksanakan tujuan dan fungsi-fungsi perpustakaan perguruan tinggi.

Adapun fungsi perpustakaan perguruan tinggi menurut Direktorat Jenderal Pendidikan Tinggi $(2004,3)$ adalah sebagai berikut:

1. Fungsi Edukasi, Perpustakaan merupakan sumber belajar para sivitas akademika, oleh karena itu koleksi yang disediakan adalah koleksi yang mendukung pencapaian tujuan pembelajaran, pengorganisasian bahan pembelajaran setiap program studi, koleksi tentang strategi belajar mengajar dan materi pendukung pelaksanaan evaluasi pembelajaran.

2. Fungsi Informasi, Perpustakaan merupakan sumber informasi yang mudah diakses oleh pencari dan pengguna informasi.

3. Fungsi Riset, Perpustakaan mempersembahkan bahan-bahan primer dan sekunder yang paling mutakhir sebagai bahan untuk melakukan penelitian dan pengkajian ilmu pengetahuan, teknologi dan seni. Koleksi pendukung penelitian di perpustakaan perguruan tinggi adalah menghasilkan karyakarya penelitian yang dapat di aplikasikan untuk kepentingan pembangunan masyarakat dalam berbagai bidang.

4. Fungsi Rekreasi, Perpustakaan harus menyediakan koleksi rekreatif yang bermakna untuk membangun dan mengembangkan kreativitas, minat dan daya inovasi pengguna perpustakaan.

5. Fungsi Publikasi, Perpustakaan selayaknya juga membantu melakukan publikasi karya yang dihasilkan oleh warga perguruan tingginya yakni sivitas akademika dan staf non-akademik.

6. Fungsi Deposit, Perpustakaan menjadi pusat deposit untuk seluruh karya dan pengetahuan yang dihasilkan oleh warga perguruan tingginya.

7. Fungsi Interpretasi, Perpustakaan sudah seharusnya melakukan kajian dan memberikan

1 http://kinerja.lib.itb.ac.id/index.php?mod=fm Diakses pada Tanggal 13-05-2013 
nilai tambah terhadap sumber-sumber informasi yang dimilikinya untuk membantu pengguna dalam melakukan dharmanya.

Berdasarkan penjelasan di atas, penulis dapat menyimpulkan bahwa perpustakaan perguruan tinggi berdasarkan fungsinya, yaitu; dapat mendukung program pendidikan, pengajaran, serta penelitian, dengan menyediakan informasi yang dibutuhkan dan melaksanakan Tri Dharma perguruan tinggi.

Dalam mendukung misi dan visi pendidikan di ITB, salah satunya tergantung pada layanan perpustakaan dalam menyediakan sumber-sumber informasi ilmiah dalam mendukung kegiatan kegiatan belajar dan mengajar. Untuk itu perpustakaan dituntut untuk mampu mengembangkan perpustakaan yang dapat selalu memenuhi kebutuhan penggunanya. Acuan yang masih relevan dipakai untuk pengembangan perpustakaan adalah SNI 7330:2009 PPT. Aspek aspek SNI 7330:2009 PPT yang menjadi acuan perencanaan pengembangan perpustakaan, sebagai berikut:

1. Pengorganisasian materi perpustakaan.

2. Pelestarian materi perpustakaan.

3. Sumber daya manusia

4. Layanan perpustakaan.

5. Penyelenggaraan perpustakaan. Yang dimaksud dengan penyelenggaraan perpustakaan adalah Setiap perguruan tinggi menyelenggarakan perpustakaan

6. Gedung perpustakaan. Standar sarana gedung perpustakaan adalah,

a. Perpustakaan harus menyediakan ruang sekurang-kurangnya $0,5 \mathrm{~m}^{2}$ untuk setiap mahasiswa.

b. Ruang koleksi. Areal koleksi seluas $45 \%$ yang terdiri dari ruang koleksi

c. Ruang pengguna seluas $30 \%$

d. Ruang staf perpustakaan seluas $25 \%$

7. Alokasi Anggaran. Alokasi anggaran perpustakaan sekurang-kurangya 5\% dari total anggaran perguruan tinggi diluar belanja pegawai.

Dari pemaparan di atas maka dalam pengembangan suatu perpustakaan diperlukan faktor-faktor yang mendukung pengembangan perpustakaan itu sendiri agar sesuai dengan SNI
7330:2009 PPT. Namun, banyak dari perpustakaan perguruan tinggi di Indonesia termasuk ITB, masih belum bisa mencapai kualitas sesuai dengan SNI 7330:2009 PPT, karena ada aspek-aspek yang termasuk kedalam standar perpustakaan yang masih belum tercapai.

Dengan meneliti kajian ini, kita dapat mengetahui bagaimana pelayanan perpustakaan bermanfaat bagi pemustaka dan bagi perpustakaan itu sendiri. Sehingga, dengan meneliti kajian pengembangan perpustakaan ini, dapat dimanfaatkan secara jangka panjang untuk mengembangankan perpustakaan dengan mutu dan standar yang sesuai dengan standarisasi, juga relevan dengan pengembangan perpustakaan adalah SNI 7330:2009 PPT.

\section{Tujuan Penelitian}

Tujuan dari penelitian ini dapat dirumuskan sebagai berikut:

Menyusun konsep perencanaan strategis perpustakaan perguruan tinggi secara jangka pendek dan jangka panjang berdasarkan alternatif strategis yang ada.

\section{Kegunaan Penelitian}

Kegunaan yang diharapkan dari penelitian ini adalah:

Kegunaan akademis, yaitu:

1. Bagi ilmu perpustakaan, dapat memperkaya khasanah penelitian terutama dalam perencanaan strategis dan pengembangan perpustakaan.

2. Sebagai bahan rujukan untuk penelitian berikutnya yang berkaitan dengan perencanaan strategis dalam pengembangan perpustakaan.

Kegunaan praktis, yaitu:

1. Bagi Perpustakaan Pusat ITB, konsep perencanaan strategis yang dihasilkan dapat sesuai dengan standar SNI PPT dan dapat dijadikan sebagai pedoman untuk penyusunan perencanaan strategis pengembangan perpustakan di masa yang akan datang.

2. Bagi Perpustakaan Pusat ITB, konsep perencanaan strategis yang sesuai dengan standar SNI PPT akan bermanfaat bagi pengembangan mutu perpustakaan

\section{FOKUS PENELITIAN DAN PERTANYAAN PENELITIAN}

Fokus Penelitian 
Bagaimana pengembangan perpustakaan berdasarkan SNI 7330:2009 PPT di Perpustakaan Pusat ITB

\section{Pertanyaan Penelitian}

1. Bagaimana pengembangan perpustakaan pada aspek Layanan di Perpustakaan Pusat ITB?

2. Bagaimana pengembangan perpustakaan pada aspek Sumber Daya Manusia di Perpustakaan Pusat ITB?

3. Bagaimana pengembangan perpustakaan pada aspek Sarana dan Prasarana di Perpustakaan Pusat ITB?

4. Bagaimana pengembangan perpustakaan pada aspek anggaran di Perpustakaan Pusat ITB?

5. Bagaimana rencana strategis dalam mencapai standar pengembangan perpustakaan yang sesuai berdasarkan SNI 7330:2009 PPT di Perpustakaan Pusat ITB?

\section{METODOLOGI}

\section{Paradigma Penelitian}

Penelitian ini menggunakan metode kualitatif yang berkaitan dengan paradigma interpretif. Jenis penelitian ini dapat digolongkan menurut kegunaan, dan penelitian ini sendiri dikategorikan/digolongkan sebagai penelitian evaluatif (Neuman 2000, 23). Studi evaluatif dilakukan untuk mengukur suatu program, kebijakan atau aktifitas pelaksanaan sebuah kegiatan/pekerjaan.

\section{Subjek dan Objek Penelitian}

Dalam penelitian ini yang menjadi subjek penelitiannya adalah informan yang terkait dengan pengembangan perpustakaan di Perpustakaan Pusat ITB. Teknik penentuan informan/narasumber dalam penelitian ini adalah menggunakan metode purposive sampling, Yaitu penentuan informan berdasarkan pertimbangan tertentu, sebagaimana disampaikan oleh Sugiyono (2011, 218), teknik pengambilan sampel sumber data dengan pertimbangan tertentu, yaitu bahwa sumber data dianggap paling tahu tentang pengembangan perpustakaan. Alasan pemilihan sumber karena dianggap memiliki keterkaitan langsung terhadap pengembangan Perpustakaan Pusat Institut Teknologi Bandung, diantaranya yaitu: Kepala Perpustakaan, kepala bidang administrasi Umum, kepala bidang pelayanan dan empat orang staf perpustakaan.

Informan kunci dari penelitian ini adalah kepala perpustakaan Pusat ITB, kemudian oleh Kepala perpustakaan disarankan untuk mewawancarai kepala bagian administrasi umum, kepala bagian layanan dan beberapa staf perpustakaan. Juga sebagai bahan perbandingan pengembangan Perpustakaan, Kepala Perpustakaan Universitas Indonesia (UI) dipilih sebagai pakar pengembangan perpustakaan.

Sedangkan objek dari penelitian ini yaitu pengembangan perpustakaan berdasarkan standar nasional Indonesia tahun 2009 nomor 7330 (SNI 2009:7330 PPT).

\section{Sumber dan Jenis Data}

Berdasarkan sumber data, yaitu data primer berupa kata-kata dan perilaku orang-orang yang merupakan bagian dalam sistem organisasi kemudian diamati, diwawancarai, dan didokumentasikan melalui pencatanan tertulis atau direkam melalui media perekam tentang sejumlah individu yang terlibat langsung dalam peristiwa pengembangan perpustakaan berdasarkan SNI 7330:2009 PPT di Perpustakaan Pusat ITB. Sedangkan data sekunder berupa dokumendokumen dan data statistik.

\section{Teknik Pengumpulan Data}

Penelitian ini adalah penelitian kualitatif yang sumber data utamanya adalah berupa data-data hasil dokumentasi, observasi, dan diperkuat dengan data tambahan berupa hasil wawancara dengan beberapa informan yang memiliki kaitan dengan proses pengembangan Perpustakaan ITB.

\section{Teknik Analisis data}

Teknik analisa data yang digunakan dalam penelitian ini bersifat induktif mengacu pada model Miles dan Huberman (Sugiyono, 2005) yang menyatakan bahwa aktifitas dalam analisis data kualitatif dilakukan secara interaktif dan berlangsung secara terus menerus. Aktifitas yang dilakukan dalam analisis ini terdiri dari tiga tahapan yaitu: (1) Reduksi data (data reduction) yaitu dengan menulis atau mencatat data dalam bentuk laporan atau uraian yang rinci. (2) Penyajian data (data display) dilakukan dengan cara mensistematisasikan pokok-pokok informasi agar dapat melihat hubungan antara data-data yang 
diperoleh. Pada tahap ini data dianalisis dengan menggunakan analisis aplikasi teori sistem dalam meneliti pengembangan perpustakaan di Perpustakaan ITB. (3) Conclusion drawing yaitu mengambil kesimpulan dan verifikasi untuk mencari makna dari data yang dikumpulkan. Dan menyusun konsep perencanaan strategis bagi pengembangan Perpustakaan ITB di masa yang akan datang.

\section{Teknik Validitas Data}

Beberapa kriteria yang digunakan dalam penelitian kualitatif, untuk keabsahan data yaitu derajat kepercayaan, keteralihan, kebergantungan, dan kepastian. Kriteria validitas data diterapkan dalam rangka membukakan temuan hasil di lapangan dengan kenyataan yang diteliti di lapangan. (Lincoln dan Guba dalam Moleong 2001, 173)

Sedangkan langkah-langkah yang dilakukan peneliti untuk dianalisis pada penelitian ini adalah: (1) Peneliti mengumpulkan data melalui peristiwa untuk dianalisis, kegiatan ini dilakukan melalui kodifikasi data, sehingga data itu ditransformasikan secara sistematis dan dapat dikategorikan sesuai dengan karakteristiknya. Kegiatannya meliputi; membuat batasan dan memilah milih data berdasarkan batasan-batasan tersebut, kemudian mengidentifikasi masingmasing data tersebut. (2) Menguraikan secara tertulis kategori-kategori itu untuk memahami semua aspek yang terdapat di dalamnya. (3) Membuat interprestasi yang memberikan perspektif peneliti untuk memberikan makna terhadap analisis disetiap data.

\section{Waktu dan Tempat Penelitian}

Penelitian ini dilakukan di Perpustakaan ITB. Penelitian ini menganalisis faktor-faktor yang berpengaruh terhadap perkembangan perpustakaan. Hasil analisisnya berupa konsep perencanaan strategis yang kemudian bisa dijadikan acuan dalam penyusunan perencanaan strategis untuk pengembangan Perpustakaan ITB di masa yang akan datang.

\section{LANDASAN TEORETIS \\ Teori Sistem}

Konsep Teori Sistem menurut (R, Wayne. P dan D. F. Faules 2002, 63), Mengemukakan bahwa bagian-bagian penting organisasi sebagai sistem adalah individu dan kepribadian setiap individu dalam organisasi. Struktur formal, pola interaksi informal, pola status dan peranan yang menimbulkan pengharapan-pengharapan. Bagianbagian inilah yang merupakan konfigurasi yang disebut sistem organisasi. Semua bagian saling berinteraksi dan berhubungan satu dengan lainnya. Proses penghubung utamanya adalah komunikasi. Konsep sistem terfokus pada pengaturan bagianbagian, hubungan antara bagian-bagian dan dinamika hubungan tersebut yang menumbuhkan kesatuan atau keseluruhan. Inti dari pemahaman teori sistem adalah "setiap bagian berpengaruh pada keseluruhan" atau sesuatu tidak ada tanpa keberadaan yang lain. Ketika organisasi dipandang sebagai sebuah sistem sosial, maka seluruh aspek harus diperhatikan atau dianggap penting.

Menurut Scott (R, Wayne.P dan D. F. Faules 2002, 63), Satu-satunya cara dalam mempelajari organisasi adalah sebagai suatu sistem. Selanjutnya menurut Scott bagian-bagian penting organisasi sebagai sistem adalah individu dalam organisasi, struktur formal, pola interaksi informal, pola status dan peranan, lingkungan fisik pekerjaan. 


\section{Kualitas Layanan Perpustakaan}

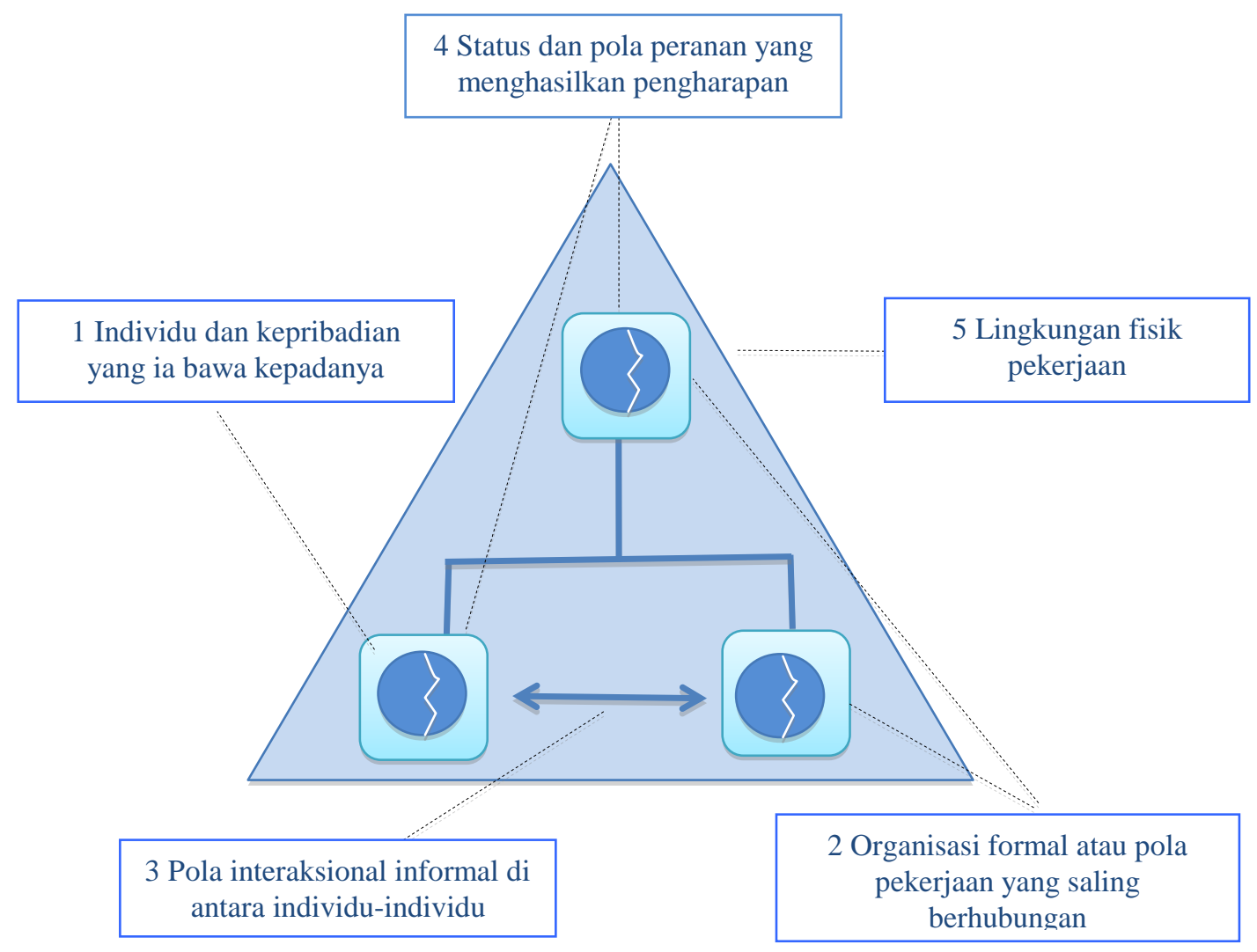

Bagian-bagian suatu sistem organisasi menurut R, Wayne. P dan D. F. Faules 2002, 64

\section{LANDASAN KONSEPTUAL}

\section{Pengembangan Organisasi}

Di dalam bukunya, Castetter. W (2004, 120150) memaparkan tentang pengembangan organisasi. Perkembangan organisasi (Organization Development/OD) adalah usaha jangka panjang dalam meningkatkan proses pembaharuan dan pemecahan masalah organisasi yang mendapat dukungan penuh dari manajemen puncak.

Tujuan dari pengembangan organisasi (PO) adalah untuk personal, profesional dan pertumbuhan organisasi. Pertumbuhan organisasi ini diarahkan oleh agen perubahan (change agent,) yaitu seseorang yang bertindak sebagai katalisator dalam pengembangan organisasi (PO) yang dinamis. Pengembangan organisasi (PO) harus direncanakan dengan baik untuk periode jangka panjang. Proses tersebut yaitu temasuk melakukan orientasi penelitian dalam metode ilmiah yang direapkan untuk menghadapi masalah-masalah organisasi yang ada. Tujuannya adalah agar orangorang yang terlibat dalam organisasi memiliki kemampuan untuk menyelesaikan permasalahan dalam organisasi. Jadi, pengembangan organisasi juga merupakan peran serta dari seluuruh anggota organisasi, agar perkembangan organisasi lebih efektif dan optimal.

\section{Standar Nasional Indonesia Perpustakaan Perguruan Tinggi (SNI PPT)}

SNI PPT merupakan kependekan dari Standar nasional Indonesia. Aspek aspek SNI 7330:2009 $P P T$, yang menjadi acuan perencanaan pengembangan perpustakaan, sebagai berikut:

1. Pengorganisasian materi perpustakaan.

2. Pelestarian materi perpustakaan.

3. Sumber daya manusia.

4. Layanan perpustakaan.

5. Penyelenggaraan perpustakaan. Yang dimaksud dengan penyelenggaraan perpustakaan adalah setiap perguruan tinggi menyelenggarakan perpustakaan.

6. Gedung perpustakaan. Standar sarana gedung perpustakaan adalah,

a. Perpustakaan harus menyediakan ruang sekurang-kurangnya $0,5 \mathrm{~m}^{2}$ untuk setiap mahasiswa 
b. Ruang koleksi. Areal koleksi seluas $45 \%$ yang terdiri dari ruang koleksi

c. Ruang pengguna seluas $30 \%$

d. Ruang staf perpustakaan seluas $25 \%$

7. Alokasi anggaran. Alokasi anggaran perpustakaan sekurang-kurangya 5\% dari total anggaran perguruan tinggi diluar belanja pegawai.

\section{Perpustakaan Sebagai Sistem}

Perpustakaan adalah sebuah sistem yang terbuka. Sistem yang terbuka mengakui adanya hubungan yang dinamis antara sistem dengan lingkungannya. Organisasi menggunakan sumber daya manusia, dan sumberdaya lainnya dari lingkungannya. Selain itu penyerapan luaran (outputs) organisasi juga tergantung kepada lingkungannya yaitu para pengguna atau pencari informasi. Sebuah sistem perpustakaan memiliki interaksi yang dinamis dengan lingkungannya. (Stueart dan Moran, 2002).

Sebagai sebuah sistem yang terbuka, pengaruh dari sistem kepada lingkungan dan lingkungan kepada sistem dapat dengan jelas dilihat. Hal ini mempengaruhi eksistensi perpustakaan. Agar perpustakaan dapat tetap survive, organisasi itu harus memanfaatkan semua sumber daya yang dimiliki, yang dikontrol oleh bermacam-macam kelompok eksternal. Sebuah organisasi yang efektif adalah yang dapat merespon kebutuhan lingkungannya dengan tepat sesuai dengan komponen yang terdapat di lingkungannya untuk suatu sumberdaya.

Menurut Yusup (2001, 61-62), teori sistem, teori sibernetik dan informasi, sering berkaitan satu dengan yang lainnya. Bedanya hanya penekanannya saja. Teori sistem lebih merujuk kepada hubungan antar bagian-bagian dalam suatu organisasi. Sementara sibernetik, berkenaan dengan aturan-aturan dan kontrol dalam sistem. Sedangkan teori informasi memfokuskan diri pada pengukuran dan transmisi tanda-tanda. Bidangbidang ini sangat banyak digunakan sebagai dasar berbagai teori komunikasi dan juga perpustakaan dalam proses dan kegiatannya.

\section{Perencanaan Strategis dalam Pengembangan Perpustakaan}

Peter Brophy dalam The Academic Library (2005) mengemukakan bahwa dalam mengembangkan perpustakaan perguruan tinggi diperlukan proses perencanaan. Perencanaan perpustakaan harus melibatkan semua unsur pimpinan dalam organisasi itu. Perencanaan strategis berhubungan dengan masa depan perpustakaan secara keseluruhan, dimana rencana lebih rinci diberikan kepada masing-masing individu, atau untuk memandu tujuan utama pengembangan seperti pemilihan dan implementasi suatu sistem manajemen perpustakaan yang baru.

Perencanaan strategis adalah suatu proses proaktif dan berkelanjutan yang memungkinkan sebuah lembaga informasi untuk memanfaatkan kekuatan-kekuatan dari luar dalam pemilihan strategi dan peningkatan kebutuhan pasar (Bryson, 1999).

\section{Kerangka Pemikiran}

Teori yang menjadi landasan penelitian ini adalah teori terapan dari ilmu biologi. Teori mendasar dalam penelitian ini adalah System Theory atau teori sistem. Prinsip dasar teori sistem sederhana menyimpulkan bahwa masyarakat merupakan suatu keseluruhan yang saling bergantung. Setiap sistem terbagi dalam sejumlah variable subsistem, dimana subsistem juga terdiri dari tatanan sub-sistem yang lebih kecil. Dalam penelitian ini dianalisis mengenai pengembangan organisasi, sedang organisasi itu sendiri adalah sistem, yang di dalamnya terdiri dari sub-sub sistem dan individu-individu yang saling berinteraksi.

Pengembangan organisasi/ perpustakaan mempengaruhi juga sistem pengelolaan perpustakaan. Cara dalam mempelajari organisasi adalah melihatnya sebagai suatu sistem. Bagianbagian penting organisasi sebagai sistem adalah individu dalam organisasi, struktur formal, pola interaksi informal, pola status dan peranan, lingkungan fisik pekerjaan. Scott dalam R, Wayne. P dan D. F. Faules (2002, 63).

Berdasarkan pemaparan di atas, maka kerangka pemikiran dari penelitian ini berjudul "Analisis Pengembangan Perpustakaan berdasarkan SNI 7330:2009 PPT Sebagai Penilaian Kualitas Layanan di Perpustakaan (Studi Evaluatif Tentang Pengembangan Perpustakaan berdasarkan SNI 7330:2009 PPT yang belum Tercapai di

Perpustakaan Pusat ITB). 


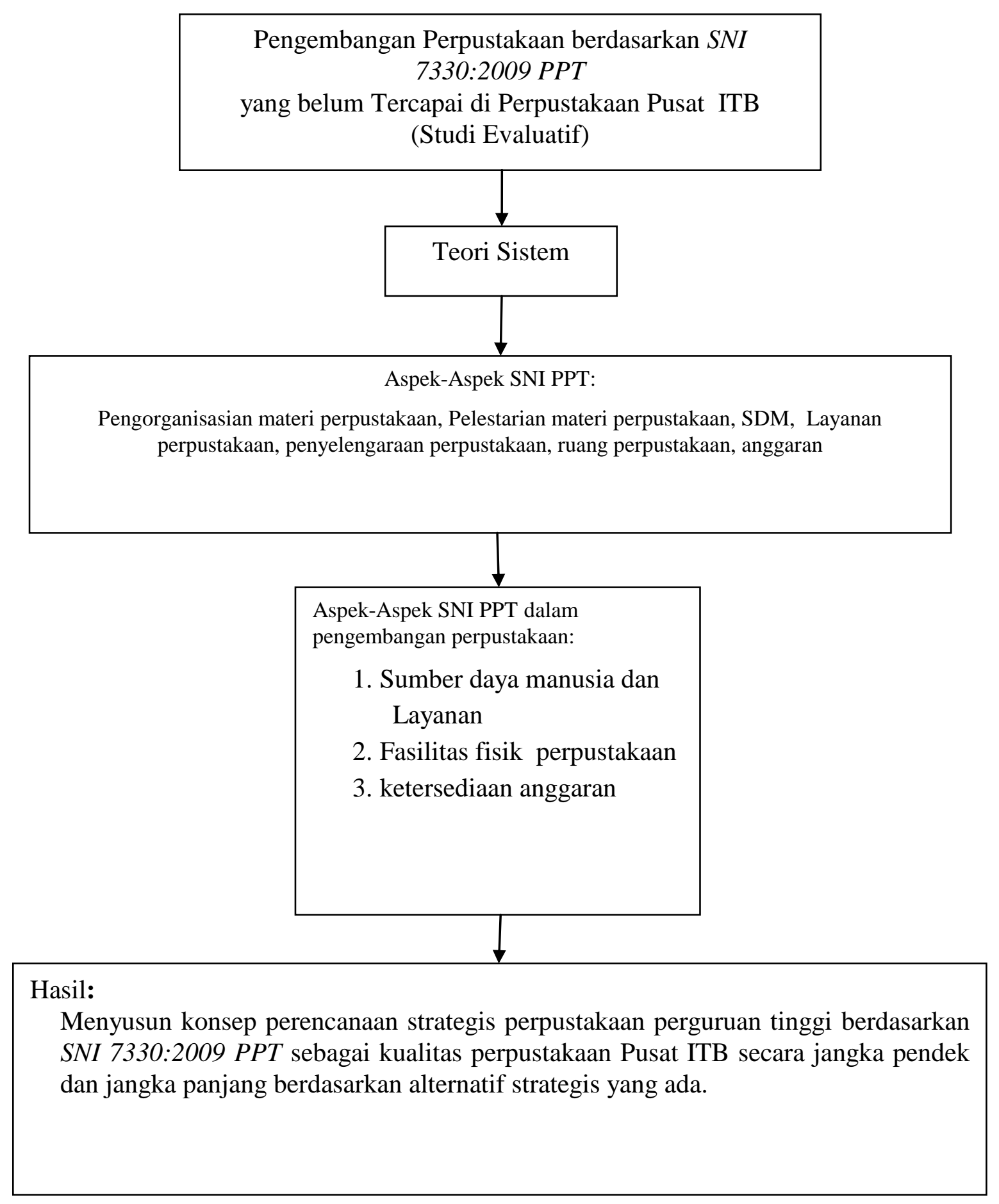

\section{HASIL DAN PEMBAHASAN}

Visi dan Misi UPT. Perpustakaan ${ }^{2}$

\section{Visi ITB}

1. UPT Perpustakaan ITB sebagai perpustakaan perguruan tinggi merupakan salah satu unsur penunjang di ITB yang ikut berperan serta

2 Executive Summary Laporan Tahunan UPT Perpustakaan Pusat ITB dalam melaksanakan tercapainya visi dan misi ITB.

2. Berdasarkan visi dan misi ITB, maka disusunlah visi dan misi UPT Perpustakaan ITB.

3. Semua program kegiatan perpustakaan ITB dilaksanakan berdasarkan visi, misi dan rencana strategis UPT Perpustakaan ITB yang telah ditetapkan. 
4. Visi, misi, dan rencana strategis UPT Perpustakaan ITB disosialisasikan kepada seluruh staf UPT Perpustakaan baik secara formal melalui berbagai pertemuan/rapat rutin, maupun secara informal dalam kegiatan yang bernuansa rekreatif maupun kegiatan yang melibatkan kebersamaan staf.

\section{Misi UPT. Perpustakaan}

Menunjang keberhasilan visi ITB dengan menyediakan layanan serta menghimpun pustaka dan akses informasi bagi sivitas akademika ITB untuk mendukung pelaksanaan Tridharma Perguruan Tinggi, dan bagi masyarakat untuk mendukung tercapainya masyarakat Indonesia berbasis pengetahuan.

\section{Kebijakan-kebijakan Rektorat (Wakil Rektor} Bidang Akademik dan Kemahasiswaan) terhadap Perpustakaan Pusat ITB

Berdasarkan SK Rektor ITB no. 046/SK/K01/KP/2010 tanggal 6 Februari 2010 dan no. 136/SK/K01/OT/2010, hubungan organisasi antara perpustakaan dan unsur lainnya di lingkungan ITB. Pada gambar terlihat bahwa Rektor mendelegasikan wewenangnya kepada Wakil Rektor yang terkait. Dalam kegiatan seharihari, Kepala UPT Perpustakaan berhubungan dengan Wakil Rektor Bidang Akademik dan Kemahasiswaan (WRAM).

\section{Struktur Organisasi Internal UPT perpustakaan ITB}

Struktur organisasi yang tercantum dalam surat Keputusan Rektor di atas, untuk kepentingan internal perpustakaan dan membantu pengurus, dibuat juga Struktur Organisasi Mikro (Internal) Perpustakaan yang mencakup fungsi-fungsi yang dilakukan di masing-masing unit di dalam organisasi Perpustakaan, struktur organisasi internal tersebut adalah seperti tercantum di bawah ini:

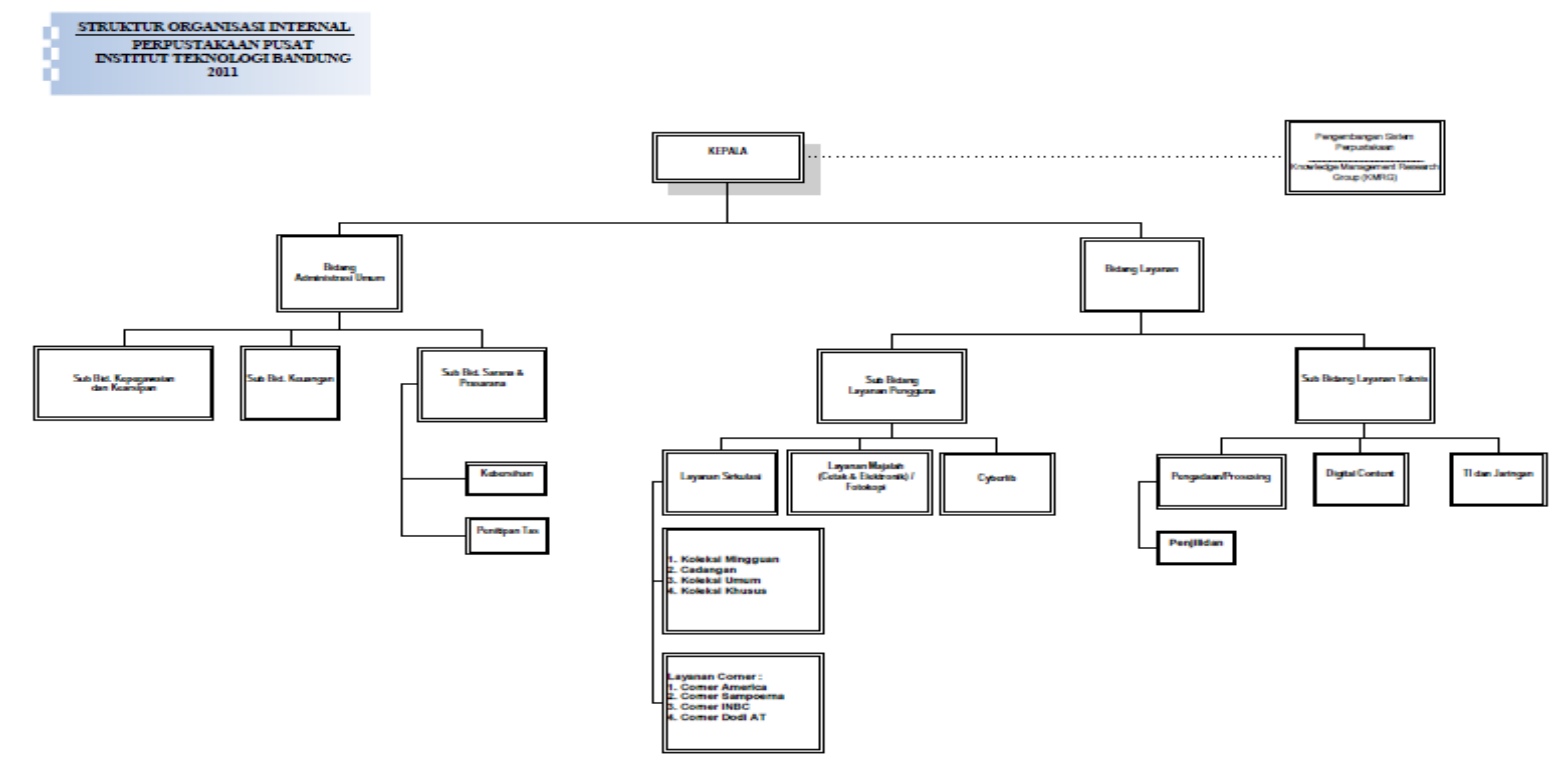

Pengembangan perpustakaan pada layanan di Perpustakaan Pusat ITB

Terkait dengan program layanan perpustakaan lainnya yaitu layanan hari Sabtu dan layanan orientasi perpustakaan, salah satu standar dalam lingkup nasional, Standar Nasional Indonesia (SNI) nomor 7330 tahun 2009 tentang
Perpustakaan Perguruan Tinggi, menetapkan bahwa jam buka perpustakaan sekurangkurangnya 54 jam perminggu dengan layanan yang diberikan, antara lain:

a. Layanan sirkulasi,

b. Layanan pinjam antarperpustakaan,

c. Layanan referensi, 
d. Layanan pendidikan pengguna. Layanan pendidikan pengguna dan literasi informasi diberikan kepada mahasiswa dan pengajar,

e. Layanan penelusuran informasi

(Sumber: BSN. 2009. SNI 7330-2009 Perpust Perguruan Tinggi)

UPT Perpustakaan selama ini telah memfasilitasi jam buka perpustakaan selama 70 jam per minggu dengan rincian, hari Senin sampai dengan Jumat dibuka mulai jam 08.00 - 21.00 WIB, dan hari Sabtu dibuka mulai jam $08.00-$ 13.00 WIB. Apabila dilakukan perbandingan dengan perpustakaan perguruan tinggi lain, maka jam buka perpustakaan perguruan tinggi terkemuka di Indonesia dapat dilihat dalam tabel berikut:

\begin{tabular}{|c|c|c|}
\hline No. & $\begin{array}{c}\text { Perpustakaan } \\
\text { Perguruan Tinggi }\end{array}$ & $\begin{array}{c}\text { Jam buka } \\
\text { perpustakaan }\end{array}$ \\
\hline 1 & $\begin{array}{c}\text { Universitas Sumatera } \\
\text { Utara (USU) }\end{array}$ & $\begin{array}{c}78 \text { jam per } \\
\text { minggu }\end{array}$ \\
\hline 2 & $\begin{array}{c}\text { Universitas Indonesia } \\
\text { (UI) }\end{array}$ & $\begin{array}{c}75 \text { jam per } \\
\text { minggu }\end{array}$ \\
\hline 3 & $\begin{array}{c}\text { Universitas Brawijaya } \\
\text { (UB) }\end{array}$ & $\begin{array}{c}72 \text { jam per } \\
\text { minggu }\end{array}$ \\
\hline 4 & $\begin{array}{c}\text { Institut Teknologi } \\
\text { Bandung (ITB) }\end{array}$ & $\begin{array}{c}70 \text { jam per } \\
\text { minggu }\end{array}$ \\
\hline 5 & Universitas Bina & 70 jam per \\
minggu
\end{tabular}

(Sumber: Hasanah, Nanan. 2009. World Class University Library. Bandung: FPPT JABAR)

Selain terkait standar jam buka layanan perpustakaan, UPT Perpustakaan menyediakan layanan hari Sabtu (Kegiatan Lembur Sabtu) atas dasar permintaan mahasiswa ITB dengan alasan karena adanya kesibukan kuliah di hari-hari biasa (yaitu, hari Senin - Jumat) sehingga pada hari Sabtu mereka dapat mengerjakan tugas perorangan atau kelompok di perpustakaan. Dalam pelaksanannya, layanan hari Sabtu banyak dimanfaatkan oleh mahasiswa dalam rangka aktivitas pembelajaran dan penelusuran informasi. Terlebih lagi ketika masa ujian sedang berlangsung, mahasiswa sering memanfaatkan layanan hari Sabtu untuk aktivitas pembelajaran. Hal ini dikarenakan waktu yang tersedia pada hari Senin sampai dengan Jumat lebih banyak tersita oleh aktivitas perkuliahan.
Tindak lanjut pada pengembangan layanan di Perpustakaan Pusat ITB

Program orientasi perpustakaan merupakan implementasi dari SNI 7330-2009 tentang Rernustakaan Perguruan Tinggi terkait layanan pendidikan pengguna. Layanan pendidikan pengguna dan literasi informasi diberikan oleh perpustakaan kepada mahasiswa dan pengajar. UPT Perpustakaan secara berkesinambungan memberikan layanan orientasi perpustakaan setiap tahun kepada mahasiswa baru baik tingkat sarjana, magister, maupun doktor. Program orientasi perpustakaan ini merupakan salah satu media promosi dan sosialisasi mengenai program layanan dan fasilitas yang disediakan UPT Perpustakaan untuk dimanfaatkan oleh mahasiswa dalam rangka sukses studi di ITB. Oleh karena itu, program orientasi perpustakaan sangat strategis dan bermanfaat untuk mahasiswa baru agar dapat mengatur strategi pembelajaran dengan memanfaatkan fasilitas yang disediakan oleh UPT Perpustakaan.

Sedangkan beberapa kondisi seperti keterbatasan jumlah staf perpustakaan yang ada dan hari Sabtu merupakan hari libur bagi ITB, maka kegiatan lembur Sabtu hanya untuk kegiatan layanan pengguna dan staf yang bersedia bekerja di hari Sabtu diberikan uang lembur. Besarnya uang lembur adalah 2 kali dari tarif hari biasa sesuai dengan SK Rektor nomor 355b/SK/K01/KU/2009 yang berkaitan dengan pemberian uang lembur dan surat arahan dari Wakil Rektor Bidang Akademik dan Kemahasiswaan dengan nomor 1254/K01.2/KP/ 2009 tanggal 24 September 2009.

\section{Pengembangan perpustakaan pada Sumber Daya Manusia di Perpustakaan Pusat ITB}

Dalam menjalankan tugasnya memimpin kegiatan penyelenggaraan layanan perpustakaan untuk periode 2012-2014, Kepala UPT Perpustakaan dibantu oleh 2 Kepala Bidang, yaitu Kepala Bidang Administrasi Umum dan Kepala Bidang Layanan. Di bawah kepala bagian ada subsub bagain yang termasuk kedalam sistem struktur organisasi untuk menjalankan Perpustakaan Pusat ITB.

Proporsi pustakawan dan tenaga administrasi tidak berimbang (30\% pustakawan dan $70 \%$ tenaga administrasi) menurut SNI 7330:2009 PPT jumlah sumber daya manusia yang diperlukan 
dihitung berdasarkan perbandingan satu pustakawan, dua tenaga teknis perpustakaan dan satu tenaga administrasi. Tambahan pula, dalam tiga tahun ke depan adan ada pensiun dan dari jumlah $60 \%$ pegawai yang pensiun adalah pustakawan.

Sumber daya manusia. Sumber daya manusia di perpustakaan, sebagian besar dari pegawai perpustakaan pusat ITB bukan berasal dari latar belakang pendidikan ilmu perpustakaan.

\section{Proporsi staf Pustakawan dan non Pustakawan}

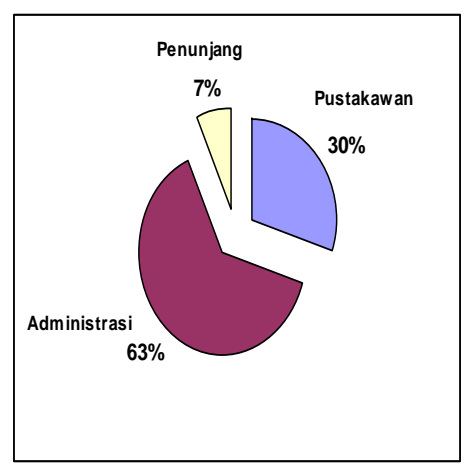

Pustakawan : $30 \%$

D1-D3 : $7 \%$

SMA : $63 \%$

Tindak lanjut pada pengembangan Sumber

Daya Manusia di Perpustakaan Pusat ITB

Komunikasi antar Pegawai

Sistem berkomunikasi antar pegawai di perpustakaan Pusat ITB sudah baik, baik secara formal maupun informal.

1. Sistem komunikasi tatap muka, yaitu:

- Sistem komunikasi tatap muka antar kepala perpustakaan kepala bagian dan sub-sub bagian; komunikasi ini dilakukan secara formal dan non-formal. Komunikasi secara non-formal yang dilakukan sudah baik. Kepala perpustakaan hampir setiap hari berkeliling ke setiap bagian untuk mengetahui perkembangan dan kebutuhan staf dalam bekerja. Sedangkan komunikasi secara formal dilakukan oleh kepala bidang administrasi umum dan kepala bidang layanan.

- Sistem komunikasi tatap muka antar kepala bagian dengan sub-sub bagian dikoordinasi oleh kepala bidang layanan dengan dibentuk tim pengembangan perpustakaan untuk membangun perpustakaan itu dengan mendeskripsikan komunikasi masing-masing dari kepala bagian dan sub-sub divisi di perpustakaan.

2.Sistem komunikasi melalui media teknologi informasi, komunikasi ini berkaitan dengan perkembangan teknologi yang dapat memudahkan komunikasi antar pegawai perpustakaan, dalam lingkup hubungan kerja antar pegawai saat ini menggunakan media komunikasi e-mail.

\section{Pengembangan SDM}

Tindak lanjut pengembangan SDM yaitu:

1. Perpustakaan ITB membuat rencana strategis yang diajukan kepada ITB Pusat, yaitu untuk merekrut pegawai setiap 1 tahun sekali secara bertahap agar standar dari Perpustakaan ITB bisa sesuai dengan SNI 7330:2009 PPT.

2. Untuk meningkatkan kinerja pengelola perpustakaan dilakukan penilaian kinerja pegawai dan pelatihan-pelatihan bidang perpustakaan, yaitu:

a. Berdasarkan aturan yang ada, sistem penilian terhadap kinerja pengelola perpustakaan dilakukan dengan cara DP3 bagi pegawai yang berstatus PNS, penilaian DP3 dilakukan untuk remunerasi para pegawai PNS yaitu mengkaji sistem penilaian kinerja untuk meningkatkan prestasi dan disesuaikan dengan tunjangan, penilaian ini dilakukan setiap akhir tahun. Sedangkan penilaian kinerja untuk seluruh pegawai berstatus pegawai BHMN dan pegawai kontrak, itu menggunakan penilaian merit system, yaitu penilaian kinerja dalam konteks penilaian 'bawahan ke atasan dan atasan ke bawahan' dan penilaian pelayanan perpustakaan yang dinilai oleh rektorat. Merit system yaitu penilaian antar teman sejawat, misalnya penilaian kepala bidang administrasi umum menilai kinerja kepala bidang layanan, biasanya penilaian ini dilakukan setiap 1 bulan sekali namun direkapitulasi setiap 1 tahun sekali. Hasilnya dinilai dalam 
bentuk angka, penilaian ini juga berkaitan dengan insentif, jika nilainya tinggi maka akan mendapatkan insentif yang tinggi sebaliknya jika nilainya rendah akan mendapatkan insentif yang rendah pula, nilai yang diberikan yaitu 4 untuk nilai yang tertinggi dan 1 untuk nilai yang terendah.

b. Pelatihan-pelatihan diselenggarakan oleh perpustakaan ITB sendiri. Di Perpustakaan Pusat ITB terdapat beberapa pelatihan kinerja pegawai perpustakaan, diantanya adalah:

- Pelatihan-pelatihan yang difasilitasi oleh Pengembangan Manusia dan Organisasi (PMO), PMO adalah sebuah wadah untuk peningkatan sumber daya manusia yang dilakukan oleh ITB. ITB melalui PMO mengadakan pelatihan dengan mengundang pakar-pakar dari bidang perpustakaan untuk melatih pegawai dan yang merekomendasikan pakarpakar tersebut dari intern Perpustakaan Pusat ITB itu sendiri.

- Pelatihan pemanfaatan e-book dan $e$ journal untuk seluruh staf perpustakaan. Pelatihan tersebut dilakukan untuk memenuhi kebutuhan para pengguna perpustakaan yang menggunakan e-book dan e-journal. Oleh karena itu berdasarkan pada tuntutan para pengguna perpustakaan, Perpustakaan pusat ITB berlangganan e-book dan e-journal.

\section{Pengembangan perpustakaan pada Sarana dan Prasarana di Perpustakaan Pusat ITB}

Perpustakaan harus menyediakan ruang sekurang-kurangnya $\quad 0,5 \mathrm{~m}^{2}$ untuk setiap mahasiswa. Kondisi eksisting luas ruangan gedung perpustakaan ITB sekarang adalah 8.983 dan jumlah mahasiswa $=21.694$ orang. Artinya kebutuhan ruang saat ini adalah 8.083/21.694= $0,3725 \mathrm{~m}^{2}$. Alokasi ruang kurang dari $0,5 \mathrm{~m}^{2}$, artinya masih belum memenuhi SNI 7330:2009 $P P T$. Berarti masih dibutuhkan beberapa ruangan untuk para mahasiswa dan pegawai melalui rencana strategis perpustakaan.

\section{Tindak lanjut pada pengembangan Sarana} Prasarana (Gedung) di Perpustakaan Pusat ITB

Kemudian tindak lanjut dari permasalahan itu akan dibuat strategi untuk mengeluarkan ruanganruangan yang secara langsung tidak berhubungan dengan perpustakaan, seperti; American corner, sampoerna corner, gothe institute digabung menjadi satu ruangan menjadi ruangan serba guna, lalu ada ruangan perpustakaan prodi yang ada di perpustakaan Pusat ITB dialihkan koleksinya, sehinga bisa menambah ruang bagi pengguna. Mengoptimalkan ruangan untuk kebutuhan pengguna perpustakaan.

\section{Pengembangan perpustakaan dalam pada Anggaran di Perpustakaan Pusat ITB}

Berdasarkan SNI 7330:2009 PPT point 12, anggaran perpustakaan sekurang-kurangnya $5 \%$ dari total anggaran perguruan tinggi diluar belanja pegawai.

Alokasi anggaran. Alokasi anggaran perpustakaan sekurang-kurangya $5 \%$ dari total anggaran perguruan tinggi diluar belanja pegawai. Kondisi eksisting penganggran perpustakaan ITB saat ini. Anggaran Belanja ITB Rp.700.000.000.000. Anggaran yang dialokasikan ke perpustakaan Rp. 2.665.343.300,00. Proporsi anggaran:

2.665.343.300,00/700.000.000.000 x $100 \%=$ $0,38 \%$.

Alokasi anggaran pengembangan perpustakaan, masih jauh dari SNI 7330:2009 $P P T$. Berarti masih dibutuhkan anggaran yang sesuai untuk mengelola dan mengembangkan perpustakaan melalui rencana strategis perpustakaan.

Tindak lanjut pada pengembangan Anggaran di Perpustakaan Pusat ITB

Anggaran yang dialokasikan untuk pengelolaan perpustakaan pusat ITB adalah dari Perpustakaan ITB sendiri, yang mengajukan kepada ITB pusat untuk operasional perpustakaan. Dalam penganggara, UPT perpustakaan selalu 
membuat Rencana Bisnis dan Anggaran (RBA). Hal ini dilakukan dengan tujuan untuk membuat suatu layanan informasi perpustakaan sesuai dengan tuntutan pengguna perpustakaan dan standar yang berlaku. Diharapkan seluruh kegiatan operasional perpustakaan dilaksanakan berdasarkan sistem perpustakaan yang efektif, efisien, dan sesuai standar yang berlaku baik lingkup nasional maupun internasional. Sistem perpustakaan yang dimaksud adalah sistem informasi perpustakaan terpadu yang mencakup seluruh proses kegiatan operasional perpustakaan, namun juga memudahkan pengguna dalam memperoleh informasi yang diperlukannya.

Penyusunan RBA UPT Perpustakaan dilakukan setiap tahun didasarkan kepada Rencana Kerja Anggaran dan laporan kinerja UPT Perpustakaan tahun sebelumnya, Pagu Anggaran Program Kelangsungan Operasi kurang lebih sama dengan pagu anggaran Kelangsungan Operasi TA. Sedangkan untuk program pengembangan, direncanakan untuk mengusulkan berbagai program yang dapat melengkapi dan meningkatkan kualitas layanan perpustakaan berdasarkan strategi yang telah ditetapkan. Jadi jika dari perpustakaan pusat mengajukan anggaran kepada bidang penganggaran ITB-Pusat, dana yang akan diberikan juga akan disesuaikan selama ini walaupun ada dana yang belum terpenuhi namun minimal setidaknya dipupayakan untuk bias sesuai dengan penganggaran standar nasional Indonesia tahun 2009.

\section{Rencana Strategis Pengembangan Perpustakaan}

Konsep pengembangan Perpustakan Pusat ITB yang diusulkan adalah sebagai berikut:

1. Perpustakaan Program Studi dan Fakultas/Sekolah merupakan bagian dari organisasi UPT Perpustakaan.

2. Sistem informasi dan manajemen layanan perpustakaan yang digunakan hanya 1 sistem yang diakomodasi oleh UPT Perpustakaan, yaitu perangkat sistem otomasi perpustakaan dan perangkat lunak GDL untuk sistem perpustakaan digital ITB. Penggunaan sistem yang sama dan penyediaan server di perpustakaan program studi dan Fakultas/Sekolah. Langkah pada tahap ini merupakan salah satu langkah penghematan dana/anggaran untuk pemeliharaan sistem informasi dan manajemen perpustakaan.

3. Sivitas akademika ITB dapat memperoleh layanan perpustakaan yang sama di seluruh perpustakaan cabang. Sivitas akademika ITB dapat melakukan proses peminjaman, pengembalian, pesan pinjam, bebas pinjam dan transaksi layanan perpustakaan lainnya di perpustakaan/titik layanan yang terdekat, tanpa memandang asal program studi dan fakultas/sekolah.

4. Koleksi yang disimpan di perpustakaan cabang/titik layanan memiliki kriteria sebagai berikut:

a. Koleksi yang memiliki subjek spesifik sesuai bidang studi yang ada di Fakultas/Sekolah yang bersangkutan.

b. Koleksi yang sering digunakan/dimanfaatkan oleh sivitas akademika di Fakultas/Sekolah yang bersangkutan.

c. Koleksi tugas akhir (S1, S2, S3) hanya tersedia dalam format digital yang dapat diakses melalui sarana komputer dan internet yang telah disediakan komputer dan internet yang disediakan, dapat digunakan pula untuk mengakses informasi ilmiah dari e-journal dan $e$ books yang dilanggan ITB melalui UPT Perpustakaan.

d. Pengadaan koleksi baru akan didistribusikan ke perpustakaan cabang/titik layanan sesuai usulan dan cakupan bidang studi di fakultas yang bersangkutan.

5. Layanan yang tersedia di perpustakaan cabang/titik layanan hanya layanan sirkulasi dan layanan pemanduan/informasi.

6. SDM yang menjalankan layanan di perpustakaan cabang, minimal sebanyak 4 (empat) orang sesuai dengan SNI 7330:2009 poin 8.2. Koordinator pelaksana perpustakaan cabang/titik layanan adalah pustakawan yang sebelumnya merupakan koordinator pelaksana perpustakaan program studi atau Fakultas/Sekolah. Koordinasi perpustakaan cabang/titik layanan dengan UPT Perpustakaan dibawah koordinasi Kepala Sub 
Bidang Layanan Pengguna dengan koordinator pelaksana perpustakaan cabang/titik layanan.

7. Koordinator perpustakaan yang telah ditetapkan oleh Program Studi atau Fakultas/Sekolah menjadi anggota Dewan Perpustakaan. Hal ini dilakukan agar pihak Program Studi atau Fakultas/Sekolah masih memiliki akses dengan UPT Perpustakaan terkait kebijakan yang berhubungan dengan kepentingan Program Studi dan Fakultas/Sekolah, terutama mengenai masalah assessment akreditasi.

8. Anggaran penyelenggaraan perpustakaan cabang/titik layanan merupakan bagian dari
RKA/RBA UPT Perpustakaan, karena perpustakaan cabang/titik layanan merupakan bagian dari organisasi UPT Perpustakaan. Pengalihan anggaran belanja pegawai dan belanja barang untuk perpustakaan dari anggaran Program Studi atau Fakultas/Sekolah dilakukan melalui koordinasi dengan Direktorat Kepegawaian dan Direktorat Keuangan.

9. Data pelaporan kinerja UPT Perpustakaan akan menjadi menyeluruh dan lengkap sesuai standar yang berlaku.

Pola Rencana Pengembangan Perpustakaan

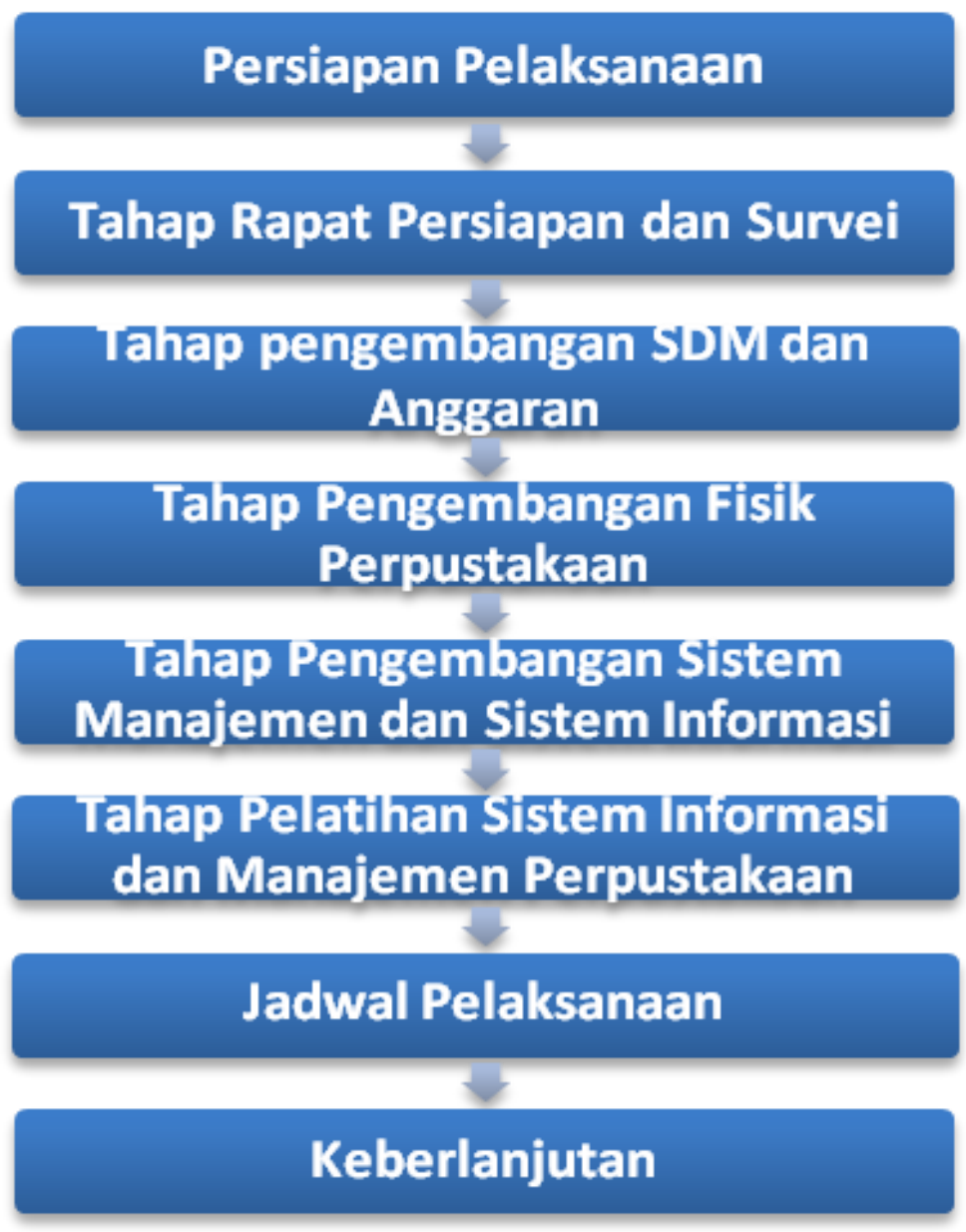

\section{Pola Kegiatan rencana pengembangan perpustakaan, meliputi:}

1. Persiapan Pelaksanaan:

Pelaksanaan program meliputi: Rapat persiapan dan survei kebutuhan/kepentingan Fakultas/Sekolah/Program Studi serta survei kondisi eksisting perpustakaan program studi, Fakultas/Sekolah, Tahap Pengalihan status SDM dan Anggaran, Tahap pengembangan fisik, Tahap Pengembangan Sistem Manajemen dan Sistem Informasi, Tahap 
Pelatihan sistem informasi dan manajemen perpustakaan.

\section{Tahap Rapat Persiapan dan Survei}

Kegiatan yang dilakukan pada tahap Rapat Persiapan dan Survei adalah sebagai berikut:

- Pembahasan dan evaluasi program /hasil survei

- Survei kebutuhan/kepentingan Fakultas/Sekolah/Program Studi

- Survei kondisi eksisting perpustakaan program studi, Fakultas/Sekolah

3. Tahap pengembangan SDM dan Anggaran

Kegiatan yang dilakukan pada tahap Pengalihan Status SDM dan Anggaran adalah sebagai berikut:

- Pengalihan Status Kepegawaian SDM berkoordinasi dengan Direktorat Kepegawaian

- Pengalihan Status Anggaran melalui koordinasi dengan Direktorat Perencanaan dan Direktorat Keuangan.

\section{Tahap Pengembangan Fisik Perpustakaan}

Kegiatan yang dilakukan pada tahap Pengembangan Fisik Perpustakaan adalah sebagai berikut: pengadaan terminal komputer, pengadaan hub, kabel, connector, pengadaan printer, pengadaan server

5. Tahap Pengembangan Sistem Manajemen dan Sistem Informasi

Kegiatan yang dilakukan pada tahap Pengembangan Fisik Perpustakaan adalah dengan (1) Pengembangan Sistem Manajemen Perpustakaan, (2) Pengembangan Sistem Informasi Layanan Otomasi Perpustakaan dan migrasi data, Pengembangan Sistem Informasi Layanan Perpustakaan Digital dan migrasi data.

6. Tahap Pelatihan Sistem Informasi dan Manajemen Perpustakaan

Kegiatan yang dilakukan pada tahap Pelatihan Sistem Informasi dan Manajemen Perpustakaan adalah Pelatihan Sistem Informasi dan Manajemen Perpustakaan dengan materi: Manajemen Pengelolaan Perpustakaan, Pemanfaatan Layanan Sistem Otomasi Perpustakaan, Pemanfaatan Layanan Sistem Perpustakaan Digital.

\section{Jadwal Pelaksanaan}

\begin{tabular}{|c|c|c|c|c|c|c|c|c|c|c|c|c|c|}
\hline \multirow{2}{*}{ Kegiatan } & \multicolumn{12}{|c|}{ Tahun Anggaran } & \multirow{2}{*}{ Ket. } \\
\hline & Jan & Feb & Mar & Apr & Mei & Jun & Jul & Ags & Sep & Okt & Nov & Des & \\
\hline $\begin{array}{l}\text { Rapat } \\
\text { Persiapan/Evaluasi } \\
\text { dan Survei }\end{array}$ & $\sqrt{ }$ & $\sqrt{ }$ & & & & & & & & & & & \\
\hline $\begin{array}{l}\text { Pengembangan } \\
\text { SDM dan Anggaran }\end{array}$ & & & $\sqrt{ }$ & $\sqrt{ }$ & & & & & & & & & \\
\hline $\begin{array}{l}\text { Pengembangan } \\
\text { Fisik Perpustakaan }\end{array}$ & & & & $\sqrt{ }$ & $\sqrt{ }$ & $\sqrt{ }$ & $\sqrt{ }$ & $\sqrt{ }$ & $\sqrt{ }$ & & & & \\
\hline $\begin{array}{l}\text { Pengembangan } \\
\text { Sistem Manajemen } \\
\text { dan Sistem } \\
\text { Informasi } \\
\text { Perpustakaan }\end{array}$ & & & & $\sqrt{ }$ & $\sqrt{ }$ & $\sqrt{ }$ & $\sqrt{ }$ & $\sqrt{ }$ & $\sqrt{ }$ & $\sqrt{ }$ & $\sqrt{ }$ & $\sqrt{ }$ & \\
\hline $\begin{array}{l}\text { Pelatihan Sistem } \\
\text { Informasi dan } \\
\text { Manajemen } \\
\text { Perpustakaan }\end{array}$ & & & & & & & & & & & & $\sqrt{ }$ & \\
\hline
\end{tabular}

\section{Keberlanjutan}

- Sistem Manajemen UPT Perpustakaan ITB yang sesuai dengan peraturan hukum yang berlaku harus terus dipelihara dan lebih ditingkatkan untuk mendapatkan sertifikasi SNI dan ISO sebagai salah satu syarat mencapai Perpustakaan berkelas dunia. Upaya pemeliharaan sistem dan peningkatan sistem dilakukan dengan program monitoring dan evaluasi sistem manajemen.

- Sistem Informasi Perpustakaan, baik sistem otomasi maupun perpustakaan digital, yang sesuai dengan standard yang berlaku agar dapat mempermudah kerjasama antarperpustakaan dalam hal layanan, pertukaran 
data, atau pemakaian bersama sumber daya informasi (resource sharing).

- Sistem Informasi dan Manajemen Perpustakaan perlu diupdate setiap tahunnya berdasarkan perkembangan yang terjadi dan permasalahan yang timbul saat implementasi sistem informasi, sehingga dapat mengakomodir data dan informasi yang dibutuhkan oleh pimpinan perpustakaan atau ITB Pusat dalam menentukan arah dan kebijakan pengembangan perpustakaan di masa depan.

\section{DAFTAR PUSTAKA}

Badan Standar Nasional. 2009. Standar Nasional Indonesia Perpustakaan Perguruan Tinggi (SNI 7330: 2009 PPT). Badan Standar Nasional.

Basuki, Sulistiyo. 2004. Pengantar Dokumentasi. Jakarta: Rekayasa Sains.

Brophy, Peter. 2005. The Academic Library. Facet Publishing, 2nd Revised edition.

Castetter, William B. 2004. The Human Resource Fuction In Educational Administration. Univercity of Pennsylvania: Prentice Hall. Seventh Edition.

Creswell, John W. 2012. Research Design: Pendekatan Kualitatif, Kuantitatif, dan Mixed. Yogyakarta: Pustaka pelajar.

ITB. 2011. Rencana Strategis Perpustakaan Pusat ITB (2011-2015). Bandung: UPT Perpustakaan ITB.

Moleong, Lexy J. 2001. Metode Penelitian Kualitatif. Bandung: Rosdakarya.

Pace, R. Wayne dan Don. F. Faules. 1993. Editor: Dedi Mulyana 2002. Komunikasi Organisasi; Strategi Meningkatkan Kinerja Perusahaan. Bandung: PT.Remaja Rosdakarya.

Stueart and Mora. 2002. Library and information center management. Colorado :Library Unlimited.

Sugiyono. 2011. Metode Penelitian Kuantitatif, Kualitatif dan R\&D Bandung: Alfabeta

Undang-undang no. 43 tahun 2007 Tentang Perpustakaan.

Yusup, Pawit. M. 2001. Pengantar Aplikasi Teori Ilmu Sosial Komunikasi untuk Perpustakaan dan Informasi. Bandung:
Program Studi Ilmu Perpustakaan. Fakultas Ilmu Komunikasi. Universitas Padjadjaran 